\title{
Apricot Kernel Oil
}

National Cancer Institute

\section{Source}

National Cancer Institute. Apricot Kernel Oil. NCI Thesaurus. Code C107264.

The oil cold-pressed from the dried seeds of the fruit of the apricot tree. Apricot kernel oil is used for frying and cooking, in the cosmetic industry, and for skin care. 